\title{
Factor-digital model of the company's capital in the context of sustainable economic development
}

\author{
Julia Lysenko ${ }^{1,2,}$, Olga Simchenko ${ }^{3}$,Evgeny Chazov $^{3}$, and Lyudmila Kamdina ${ }^{4}$ \\ ${ }^{1}$ Financial University under the Government of the Russian Federation, st. Workers, 58, 454084 \\ Chelyabinsk, Russia \\ ${ }^{2}$ South Ural State Humanitarian-Pedagogical University, Ave. Lenin, 69, 454080 Chelyabinsk, Russia \\ ${ }^{3}$ Izhevsk State Technical University named after M.T. Kalashnikov, Studencheskaya, str. 7, 426069 \\ Izhevsk, Russia \\ ${ }^{4}$ Chelyabinsk State University, Bratiev Kashirinyh Str., 129, 454001 Chelyabinsk, Russia
}

\begin{abstract}
The article discusses methodological, methodological and practical approaches to the development of a factor-digital model in the context of sustainable economic development for optimizing the capital structure, which focuses on the principles of the concept, including the effective use of equity capital, return on equity; the need for efficient use of borrowed capital. It is the balance sheet component that provides a comparison of group criteria for enhancing financial and economic activity. During COVID-19 and the post-pandemic state, the schemes of proof algorithms for equity capital play an important role in the practical application of the factor-digital capital model, which allows in practice to skillfully manage group criteria: cash flows (financial, investment, etc.), liquidity and solvency.
\end{abstract}

\section{Introduction}

Today, in uncertain conditions, the risk factor of failure to pay off their obligations and debts on the part of counterparties is quite high, and, as a result, the discipline of finance is "lame". In this regard, great importance is attached to diagnostics of the subject's ability to pay liabilities, also to diagnose asset turnover, diagnose the risk factor taking into account group criteria.

For all this, added to this is the creation of a factor-digital capital model and an assessment of the risk factor of insecurity.

With regard to receivables, when diagnosing liquidity and solvency, inflows and outflows of cash flows, the main attention is paid to any criterion, for example, stocks, since the formation of "illiquid" stocks negatively affects liquidity and solvency, cash inflow and outflow, withdraws cash flows from circulation, is disrupted the content of the asset turnover criterion. But at the same time, the main reporting form is the form "Cash flow statement" in financial accounting, in which the liquidity and solvency, cash flows of

\footnotetext{
*Corresponding author: lysenkoyulia@mail.ru
} 
the company are presented in the most informative way. At the expense of it, the conduct of current settlements and payments is monitored: how cash flows were received; to what extent all debt obligations have been repaid; what are the balances of cash flows by type of activity (financial, investment, current activity) at the disposal of the company after current settlements and payments; what was the degree of asset turnover and the effect of the formation, distribution and use of cash flows. In this regard, the diagnostics of cash receipts directly shows what is the risk factor of insecurity, which can potentially exist in uncertain conditions.

The study is relevant in that it includes the development of a methodology, methodology and practice for diagnostics and group assessment of the risk factor of insecurity, it fragmentarily details the categories of criteria for liquidity and solvency, cash flows, asset turnover and performance.

To achieve long-term success in goal setting, it is necessary to provide for the solution of a whole range of tasks:

evaluation of a variety of approaches of different authors' positions to the subject area of diagnostics and group assessment of risk factors of insecurity, taking into account the proposed criteria;

the need to develop analytical tools for modeling the risk factor, building algorithms for its practical application;

development of a methodology, methodology and practice for group assessment of risk factors of insecurity for Russian companies;

development of conceptual foundations for modeling asset turnover management, management of cash inflow and outflow, liquidity and solvency management in order to minimize the risk factor as insecurity.

This study should be based on the following assumptions:

asset turnover management, cash inflow and outflow management, liquidity and solvency management in order to achieve efficiency cannot do without a sales channel for a specialized product range, which may result from the formation of accounts receivable;

in order to minimize the risk factor, it is necessary to develop new methodological and methodological tools, algorithms for the application of modeling asset turnover management, cash inflow and outflow management, liquidity and solvency management in order to diagnose and manage risk factors of possible bankruptcy;

the importance of developing a theoretical-methodological, theoretical-methodological, practical design of diagnostics and assessment of the bankruptcy risk factor.

Bottom line: it is necessary to diagnose the experience of the constituent entities of the Russian Federation that effectively apply asset turnover management, cash inflow and outflow management, liquidity and solvency management, which will have a positive effect on reducing insecurity risk factors.

\section{Materials and methods}

The study was carried out on the basis of materials from the Ural Federal District, on the basis of materials from Russian companies that produce and sell more than 50 types of mining equipment. The study was carried out among joint stock companies of the constituent entity of the Russian Federation.

The performed diagnostics of the activities of joint-stock companies specializing in the production and sale of mining equipment complexes established that the data for the groups of companies have the dynamics of average indicators: profit from sales during the lacdown period decreased by $10.6 \%$; administrative expenses decreased by $8.04 \%$.; selling expenses 
decreased by $28.73 \%$; gross profit decreased by $40.47 \%$; the cost of production increased by $20.27 \%$; revenue decreased by $25.86 \%$.

The assets of some joint stock companies have undergone certain shifts:

in 2019-2020 the cost of non-current assets increased due to the renewal of fixed assets: by $11.51 \%$; in $2018-2019$ non-current assets increase by $11.85 \%$. At the same time, accounts receivable increased by $11.23 \%$, which is assessed as a negative value for liquidity and solvency, asset turnover, cash inflow and outflow; in 2018-2019 current assets decreased by $2.06 \%$, which affected the decrease in cash flows.

Thus, the assets of the company JSC Kopeysk Machine Building Plant decreased, equity capital decreased by $3.45 \%$ due to retained earnings (loss) during the lacdown period, and an increase in accounts payable by $10.98 \%$ also negatively affects.

Thus, at present, for the Ural region, specialized companies for the production and sale of mining equipment, it is necessary to work out the following conditions: control measures for accounts payable, liquidity and solvency, inflow and outflow of cash flows.

\section{Results and Discussion}

The study showed that there are various methods of assessing insecurity, which are used in order to the onset of risk factors for bankruptcy, thanks to the developed criteria. The historical aspect of the vulnerability assessment methodology is presented in Table 1 .

Table 1. Historical background of the vulnerability assessment methodology

\begin{tabular}{|l|l|}
\hline $\begin{array}{l}\text { Original application / } \\
\text { chronological cycle }\end{array}$ & Name of the developed methodology for assessing insecurity \\
\hline 1909 until now & Rating model «Moody's» \\
\hline 1916 until now & Rating model «S\&P» \\
\hline 1924 until now & Rating model «Fitch» \\
\hline 1868 & «Z-model» Altman \\
\hline 1977 & Model «Zeta» \\
\hline 1999 & Methodology "Dontsova and Nikiforova" \\
\hline 2000 & «Moody's KMV RiskCalc v1.0» \\
\hline 2010 & «Moody's KMV RiskCalc v3.1 Russia» \\
\hline 2011 & Model "Sinelnikova" \\
\hline 2011 & The Interfax Business Due Diligence Model \\
\hline 2013 & Model "Assessment of financial risk factors of the firm" Interfax " \\
\hline
\end{tabular}

«Z- model» is one of the key models. It was developed by Edward Altman, a financial research professor at New York University. The model was developed in 1968 and is the most used in practical research and is often used for assessing insecurity. This model provides a probabilistic assessment of the onset of the bankruptcy risk factor, which is based on calculations based on accounting data (financial statements). The model consists of five significant variables, which are presented in Table 2.

Table 2. Assessment of the risk factor used in Altman's calculations

\begin{tabular}{|l|l|l|l|}
\hline $\begin{array}{l}\text { Variable risk factor } \\
\text { (xn) }\end{array}$ & $\begin{array}{l}\text { Average values for } \\
\text { groups of unsecured } \\
\text { companies, \% }\end{array}$ & $\begin{array}{l}\text { Average values for } \\
\text { groups of wealthy } \\
\text { companies, \% }\end{array}$ & «F- statistics» \\
\hline Investment / Liabilities & 40.1 & 247.7 & 33.26 \\
\hline Sales revenue / Assets & 150 & 190 & 2.84 \\
\hline Equity / Assets & -6.1 & 41.4 & 32.60 \\
\hline
\end{tabular}


Table 2. Continued

\begin{tabular}{|l|l|l|l|}
\hline $\begin{array}{l}\text { Retained earnings } \\
\text { (loss) / Assets }\end{array}$ & -62.6 & 35.5 & 58.86 \\
\hline $\begin{array}{l}\text { Balance sheet profit / } \\
\text { Assets }\end{array}$ & -31.8 & 15.4 & 26.56 \\
\hline
\end{tabular}

The exclusion of the fifth variable led to a decrease in the predictive ability of the model. Based on this, it was concluded that it is the discriminant five-factor function that has the greatest prognostic value.

The fifth variable was excluded due to the fact that this function reduces the predictive power of this model. The model is built as follows

$$
Z=1,2 x_{1}+1,4 x_{2}+3,3 x_{3}+0,6 x_{4}+0,999 x_{5},
$$

где $\mathrm{Z}$ - insecurity index; $\mathrm{xn}$ - value $\mathrm{n}$ - risk factor.

The results of corporate governance suggest that Altman's "Z-model" provides a high accuracy of the probabilistic forecast of a company's bankruptcy within one to two years. But it can only be applied to large specialized companies that make up a complete set of financial statements. Thus, the following assumptions have been made that it is the diagnostics of the inflow and outflow of cash flows that will make it possible to assess the risk factor of insecurity.

Let us assess the possibilities of modeling in order to diagnose and assess the risk factor of the company's lack of security, substantiating the content for each direction in the proposed factor-digital capital model, using group coefficients (Table 3).

Table 3. Factor-digital model diagnostics of capital and assessment of the risk factor of the company's lack of security

\begin{tabular}{|c|c|c|}
\hline $\begin{array}{l}\text { Analytical focus } \\
\text { and assessment of } \\
\text { risk factors for } \\
\text { insecurity }\end{array}$ & Explanation & Group coefficient composition \\
\hline $\begin{array}{l}\text { Assessment } r \text { of } \\
\text { balance sheet } \\
\text { liquidity and } \\
\text { calculation of group } \\
\text { convertibility ratios }\end{array}$ & $\begin{array}{l}\text { Grouping of assets according to } \\
\text { the speed of transformation into } \\
\text { cash flows in order to } \\
\text { characterize the provision of the } \\
\text { most liquid assets, determining } \\
\text { the possibility of repayment of } \\
\text { the most urgent liabilities }\end{array}$ & $\begin{array}{l}\text { Grouping of assets by degree of } \\
\text { liquidity: } \\
\text { A1 - absolutely liquid assets; } \\
\text { A2 - quickly realizable assets; } \\
\text { A3 - slow-moving assets; } \\
\text { A4 - hard-to-sell assets. Grouping of } \\
\text { liabilities according to the maturity of } \\
\text { liabilities: } \\
\text { P1 - the most urgent obligations; } \\
\text { P2 - short-term liabilities; } \\
\text { P3 - long-term liabilities; } \\
\text { P4 - permanent liabilities. } \\
\text { Group liquidity ratios: absolute } \\
\text { liquidity; urgent liquidity; current } \\
\text { liquidity. }\end{array}$ \\
\hline $\begin{array}{l}\text { Assessment } \\
\text { restoration } \\
\text { solvency }\end{array}$ & $\begin{array}{l}\text { Determination of a trend } \\
\text { towards an increase (decrease) } \\
\text { in current liquidity }\end{array}$ & $\begin{array}{l}\text { Solvency recovery ratio; } \\
\text { Loss of solvency ratio; } \\
\text { Factor analysis of current liquidity. }\end{array}$ \\
\hline $\begin{array}{l}\text { Assessment of the } \\
\text { turnover of current } \\
\text { assets }\end{array}$ & 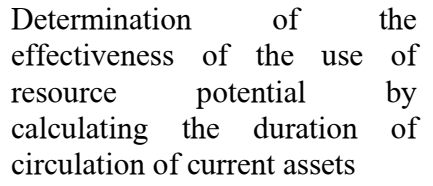 & $\begin{array}{l}\text { The turnover ratio of current assets; } \\
\text { Cash turnover ratio; } \\
\text { Accounts receivable turnover ratio; } \\
\text { Accounts payable turnover ratio; } \\
\text { Inventory turnover ratio }\end{array}$ \\
\hline
\end{tabular}


Table 3. Continued

\begin{tabular}{|l|l|l|}
\hline $\begin{array}{l}\text { Cash flow liquidity } \\
\text { assessment }\end{array}$ & $\begin{array}{l}\text { Determination of the adequacy } \\
\text { of cash inflows for the purpose } \\
\text { of making current payments and } \\
\text { settlements }\end{array}$ & $\begin{array}{l}\text { Group liquidity ratios: } \\
\text { The total cash flow taking into account } \\
\text { the cash balance at the beginning of the } \\
\text { period; } \\
\text { Cash flow from operations related to } \\
\text { the financial component; Cumulative } \\
\text { cash flow; } \\
\text { Cash flow from investment } \\
\text { transactions; } \\
\text { Cash flow from current operations. }\end{array}$ \\
\hline $\begin{array}{l}\text { Evaluating thectiveness } \\
\text { cash flows }\end{array}$ & $\begin{array}{l}\text { Determination of the } \\
\text { possibilities for the formation of } \\
\text { free stocks of funds for a } \\
\text { specific period after making } \\
\text { current payments and } \\
\text { settlements }\end{array}$ & $\begin{array}{l}\text { Group efficiency ratios: } \\
\text { Cash flow from operations related to } \\
\text { Cash flow from investment operations; } \\
\text { Cash flow from current operations; } \\
\text { Cumulative cash flow }\end{array}$ \\
\hline $\begin{array}{l}\text { SWOT- analysis as } \\
\text { an emerging risk } \\
\text { factor of insecurity }\end{array}$ & $\begin{array}{l}\text { Determination of opportunities } \\
\text { for repayment of existing } \\
\text { obligations (accounts payable), } \\
\text { identification of threats, risk } \\
\text { factor of insecurity and the } \\
\text { prospect of ways to reduce them }\end{array}$ & $\begin{array}{l}\text { Strengths based on the analysis of } \\
\text { liquidity and solvency; } \\
\text { Weak sides; The company's capabilities } \\
\text { in terms of early repayment of } \\
\text { obligations; } \\
\text { Insolvency risks }\end{array}$ \\
\hline
\end{tabular}

The main thing in the presented factor-digital capital model is the assessment of the inflow and outflow of cash flows and their relationship with the balance sheet component as an assessment of the adequacy of the asset turnover in order to pay off current payments and settlements. The necessary diagnostics and assessment of the risk factor of insecurity (accounts payable, etc.) using the reporting form "Cash flow statement", financial accounting, describes the groups of sources of formation, distribution and use of cash flows and made current settlements and payments.

It seems important to supplement the assessment of liquidity and solvency, balance sheet components and the calculation of all group liquidity and solvency ratios by analyzing the turnover of funds.

\section{Conclusions}

According to the results of the research work, it is necessary to dwell in detail on the results achieved: the concepts of various authors are disclosed to the subject areas of diagnostics and assessment of the risk factor of insecurity (accounts payable, etc.) of the company. Management of liquidity and solvency of the company will allow you to control the implementation of current settlement and payment conditions. So, insolvency is the inability to pay for your obligations (long-term, short-term).

The authors consider it expedient to supplement the diagnostics of liquidity and solvency with an analysis of the inflow and outflow of cash flows, which make it possible to effectively manage asset turnover, manage liquidity and solvency, manage the outflow and inflow of the company's cash flows: the importance of building a factor-digital capital model and assessing the risk factor of insecurity is argued. The study of theoretical and methodological, theoretical and methodological approaches, various author's positions, allows to formulate a separate author's view on the methodology and methodology for diagnosing and assessing the risk factor of insecurity, as well as developing an algorithm for applying the factor-digital capital model relative to the one specialized for mining 
companies; approbation of a fundamentally new methodology, diagnostics and assessment of the risk factor of insecurity on the example of the company JSC "Kopeysk Machine Building Plant".

The main problems in the company JSC "KMZ" are as follows: there is a very high share of reserves, a low "threshold" of both absolute and standard values of the liquidity and solvency ratio, cash flows. To solve these problems, according to the concept of the factor-digital capital model, where the criteria and features of asset turnover management, liquidity and solvency management, cash flow management are grouped are possible in the following ways: to reduce stocks; use factoring to minimize short-term receivables. Sales of receivables for factoring to a commercial bank, which will ensure the planned growth of liquidity and solvency, turnover of receivables from 46 days to 13 days.

Acknowledgements

The study was carried out with the financial support of thezhevsk State Technical University named after M.T. Kalashnikov in the framework of grant contract No. SAS / 20 20-10

\section{References}

1. A. N. Baranov, Journal of Economics and Society, 6(37), 228 (2017)

2. E.V. Zotova, T.V. Butler, Studium, 2(43), 5 (2017)

3. N.O. Ilyina N.O., Ukolova S.I., Politics, Economics, and Innovation, 2(12), 10 (2017)

4. E.A. Karzaev, V.A. Karzayev, Financial Management, 1, 17 (2017)

5. O.G. Kovalenko, A.A. Kurilova, Karelian scientific journal, 4(17), 142 (2016)

6. O.G. Kovalenko, Vestnik NGIIE, 12(67), 153 (2016)

7. N.F. Kolesnik, Yu.N. Stanchulyak, Financial analytics: problems and solutions, 2(332), 192 (2017)

8. K.K. Konstantinov, Actual problems of the humanities and natural sciences, 5-4, 60 (2017)

9. R.R. Kurmaleeva, S.I. Grudina, Scientific Review, 17, 58 (2017)

10. A.S. Nagapetyan, S.V. Kulai, Economics and society, 2(33), 732 (2017)

11. S.A. Tronin, Humanities and Economics, 2(11), 84 (2017)

12. V. N. Fashchevsky, Finance, 3, 33 (2017) 